\title{
ECC
}

\section{Modified nano- $\gamma$-alumina with 2, 4-dinitrophenyl hydrazine as an efficient adsorbent for the removal of everzol red 3BS dye from aqueous solutions}

\author{
Ayub Parchebaf Jadida, Gasem Nojameh ${ }^{\mathrm{b}, *}$ \\ ${ }^{a}$ Department of Chemistry, Ardebil Branch, Eslamic Azad University, Ardebil, Iran \\ ${ }^{b}$ Department of Chemistry, Payame Noor University, Ardebil, Iran
}

Received: 10 May 2019, Accepted: 15 June 2019, Published: 14 December 2019

\begin{abstract}
In the presented study, a new and efficient sorbent for the removal of Everzol Red 3BS dye from aqueous solutions was prepared by immobilization of 2,4-dinitrophenyl hydrazine (DNPH) on $\gamma$-alumina $\left(\gamma-\mathrm{Al}_{2} \mathrm{O}_{3}\right)$ nanoparticles coated with sodium dodecyl sulfate (DNPH- $\gamma$-alumina). The structure and morphology of the produced sorbents were characterized by Fourier Transform Infrared (FT-IR) and Scanning electron microscopy (SEM). Batch studies were performed to study the effect of various experimental parameters such as contact time, initial dye concentration, adsorbent dose and solution $\mathrm{pH}$ on the adsorption process. The experimental data were analyzed using the Langmuir and Freundlich isotherm models. The isotherm studies showed that the adsorption experimental data were fitted by Langmuir isotherm model. The maximum monolayer adsorption capacity $\left(\mathrm{q}_{\max }\right)$ obtained from the Langmuir model was 10.21 and $86.96 \mathrm{mg} / \mathrm{g}$ for Everzol Red 3BS dye on nano- $\gamma$-alumina and DNPH modified $\gamma$-alumina nanoparticles (DNPH- $\gamma$-alumina), respectively. Meanwhile, thermodynamic parameters such as Gibbs free energy $\left(\Delta \mathrm{G}^{\circ}\right)$, enthalpy $\left(\Delta \mathrm{H}^{\circ}\right)$ and entropy $\left(\Delta \mathrm{S}^{\circ}\right)$ were evaluated. We found out that $\Delta \mathrm{G}^{\circ}, \Delta \mathrm{H}^{\circ}$, and $\Delta \mathrm{S}^{\circ}$ for nano- $\gamma-$ alumina and DNPH modified $\gamma$-alumina nanoparticles (DNPH- $\gamma$-alumina) are -11.07 and $-4.84 \mathrm{~kJ} / \mathrm{mol}, 1.40$ and $3.55 \mathrm{~kJ} / \mathrm{mol}$, and 0.037 and $0.025 \mathrm{~kJ} / \mathrm{molK}$, respectively. The negative values of Gibbs free energy change $\left(\Delta \mathrm{G}^{\circ}\right)$ show that the adsorption was feasible as the spontaneous and positive values of enthalpy change $\left(\Delta \mathrm{H}^{\circ}\right)$ confirm the endothermic adsorption. The obtained results indicate that $\gamma$-alumina $\left(\gamma-\mathrm{Al}_{2} \mathrm{O}_{3}\right)-$ nanoparticles modified with 2, 4-dinitrophenyl hydrazine (DNPH- $\gamma$-alumina) can be used as an efficient adsorbent material for the adsorption of anionic dyes from aqueous solutions.
\end{abstract}

Keywords: Modified $\gamma$-alumina; 2, 4-dinitrophenyl hydrazine; sodium dodecyl sulfate; EverzolRed 3BS dye; Langmuir isotherm.

\section{Introduction}

In the last few decades, with an increase in the urbanization and industrialization, there is an increase in the use of synthetic dyes in the different industries such as textiles, leather, paper, printing, carpet, rubber, plastics, food, pharmaceutical, cosmetic, etc. [1-8]. 
The release of important amounts of synthetic dyes from various sources to the environment is one of the world's major environmental problems due to their adverse effects to many forms of life [9]. Therefore, effective removal of dyes and pigments from wastewater is environmentally important [10]. Synthetic dyes based on the chemical structure are classified into groups such as azo, anthraquinone, sulfur, triphenylmethane, and phataolcyanine compounds, etc [11]. Among these, azo dyes are a largest and most versatile class of organic dyestuffs, and more than half of the annually produced dyes are azo dyes [12]. These compounds have an azo band $(-\mathrm{N}=\mathrm{N}-)$ and because of their low cost, variety, solubility and stability are the most common synthetic dyes used for dying $[13,14]$. There are aromatic rings in the azo dye molecular structures which cause these effluents to be toxic and mostly non-biodegradable; therefore, becoming an important source of environmental pollution [15]. Hence, removal of these dyes from aqueous system is an urgent task for abbreviating the water pollution [17,18]. Various treatment technologies such as adsorption, membrane separation, ionexchange, photo-degradation, coagulation/flocculation, chemical oxidation, electrochemical oxidation, biological process, etc. have been used for the removal of dyes from wastewaters [19-24]. However, most of the mentioned methods have some disadvantages to dye removal, such as expensive, the secondary pollution, and unrecoverable [25]. Among these, the adsorption technique is one of the most efficient methods for the removal of the dyes from colored wastewaters due to its simplicity, cost-efficiency and ease of operation [26-29]. To date, many adsorbents such as activated carbon, silica gel, Zeolites, clay minerals, ion- exchange resins, metal oxides, etc. have been used to remove dyes from waters [30-34]. Among the available adsorbents, nano-sized metal oxides including $\mathrm{Fe}_{2} \mathrm{O}_{3}, \mathrm{Fe}_{3} \mathrm{O}_{4}, \mathrm{TiO}_{2}, \mathrm{SiO}_{2}$, $\mathrm{Al}_{2} \mathrm{O}_{3}, \mathrm{MgO}$ and $\mathrm{CeO}_{2}$ are being successfully employed in removal process due to their large surface areas and high available surface adsorption site density, special functionality, and defined morphology $[35,36]$. Recently, the use of nanometer-sized materials for the removal of pollutants has become an interesting area of research due to their unique properties such as high surface area, high surface area to volume ratio, high adsorption capacity, ease of modification, and diversity in surface functionalization [37]. $\quad \gamma-\mathrm{Al}_{2} \mathrm{O}_{3}$ nanoparticles are promising materials as suitable adsorbents because of their large specific surface area, high chemical activity, high adsorption capacity, mechanical strength and low temperature modification [38,39]. To increase the adsorption efficiency, chemical or physical modification of the surface $\gamma-\mathrm{Al}_{2} \mathrm{O}_{3}$ nanoparticles with certain functional groups is necessary [40]. The major aim of this study is to introduce modified $\gamma-\mathrm{Al}_{2} \mathrm{O}_{3}$ nanoparticles by 2, 4-dinitrophenyl hydrazine (DNPH) to enhance its adsorptive characteristics during removal of azo dyes from aqueous solution. In this work, 2, 4-dinitrophenyl hydrazine (DNPH) was chemically immobilized on the surface of $\gamma$-alumina as a new adsorbent for removing of Everzol Red 3BS dye from aqueous solution. The effects of various parameters such as $\mathrm{pH}$ of the solutions, initial dye concentration, adsorbent dosage, contact time, adsorption isotherm and the adsorption thermodynamics of Everzol Red 3BS dye was studied. 


\section{Methjod and Materials}

Chemicals and reagents

All chemicals were of analytical grade from Merck and used without further purification. All solutions and their dilutions were prepared using double distilled water. Nano- $\gamma-\mathrm{Al}_{2} \mathrm{O}_{3}$ (average size of $20 \mathrm{~nm}$ ) with purity $99.9 \%$ was purchased from Plasmachem GmbH. 2, 4-Dinitrophenylhydrazine (DNPH) and sodium dodecyl sulfate (SDS) were purchased from Merck. $\mathrm{pH}$ adjustments were performed with $0.1 \mathrm{~mol} \mathrm{~L}^{-1} \mathrm{HCl}$ and $\mathrm{NaOH}$ solutions. The adsorbateEverzol Red 3BS as an anionic azo dye (chemical formula= C32H29CIN7Na5O19S6, Molecular weight $=1136.32$ ) was purchased from the Textile Factory, Ardabil. The chemical structure of Everzol Red 3BSis presented in Figure 1. A stock solution required for subsequent experiments was prepared by dissolving Everzol Red 3BSin deionized water.

In this study, the nano- $\gamma$-alumina and DNPH modified $\gamma$-alumina nanoparticles (DNPH- $\gamma$-alumina) as a sorbent were prepared and their structure and morphologies were characterized by FT-IR and SEM. After characterizing, the prepared nanoadsorbents were used as a potential adsorbent for the Everzol Red 3BS removal from aqueous solutions by batch technique. The FT-IR spectra using $\mathrm{KBr}$ of $\gamma$-alumina and DNPH modified $\gamma$-alumina nanoparticles are shown in Fig. 2. For the pure $\gamma$-alumina, a broad absorption band at $3488 \mathrm{~cm}^{-1}$ can be attributed to the stretching of the framework Al-OH group. Moreover, the absorption band at $827 \mathrm{~cm}^{-1}$ is assigned to Al-O-Al symmetric stretching (Fig. $2 a)$. After modification of the $\gamma$-alumina nanoparticles with 2,4-dinitrophenyl hydrazine (DNPH), it showed a broad band in the $3500-3200 \mathrm{~cm}^{-1}$ region which is due to stretching vibrations of $\mathrm{OH}$ or $\mathrm{N}-\mathrm{H}$ groups with varying degrees of $\mathrm{H}$ bonding. The absorption bands at $1490 \mathrm{~cm}^{-1}$ and at $1620 \mathrm{~cm}^{-1}$ are attributed to the bending vibration of $\mathrm{N}$ $\mathrm{H}$ group, while N-H stretching (3200$3500 \mathrm{~cm}^{-1}$ ) and $\mathrm{C}-\mathrm{N}$ stretching (1030$1230 \mathrm{~cm}^{-1}$ ) overlap with the broad absorption band of the Al-OH group and the Al-O-Al vibrations (Fig. 2b). Comparison of the FT-IR spectrum of $\gamma$ alumina with DNPH modified $\gamma$ alumina indicated that the DNPH molecules modified the $\gamma$-alumina nanoparticles. A comparison of these characteristic spectral bands indicated that the surface DNPH- $\gamma$-alumina contained -NH-functional group as a result of the immobilization procedure.<smiles>O=C(COS(=O)(=O)Oc1cccc(Nc2nc(Cl)nc(Nc3cc(S(=O)(=O)O[Na])cc4cc(S(=O)(=O)O[Na])c(N=Nc5ccc6c(S(=O)(=O)O)cccc6c5S(=O)(=O)O)c(O)c34)n2)c1)OS(=O)(=O)O</smiles>

Figure 1. The chemical structure of Everzol Red 3BS dye 

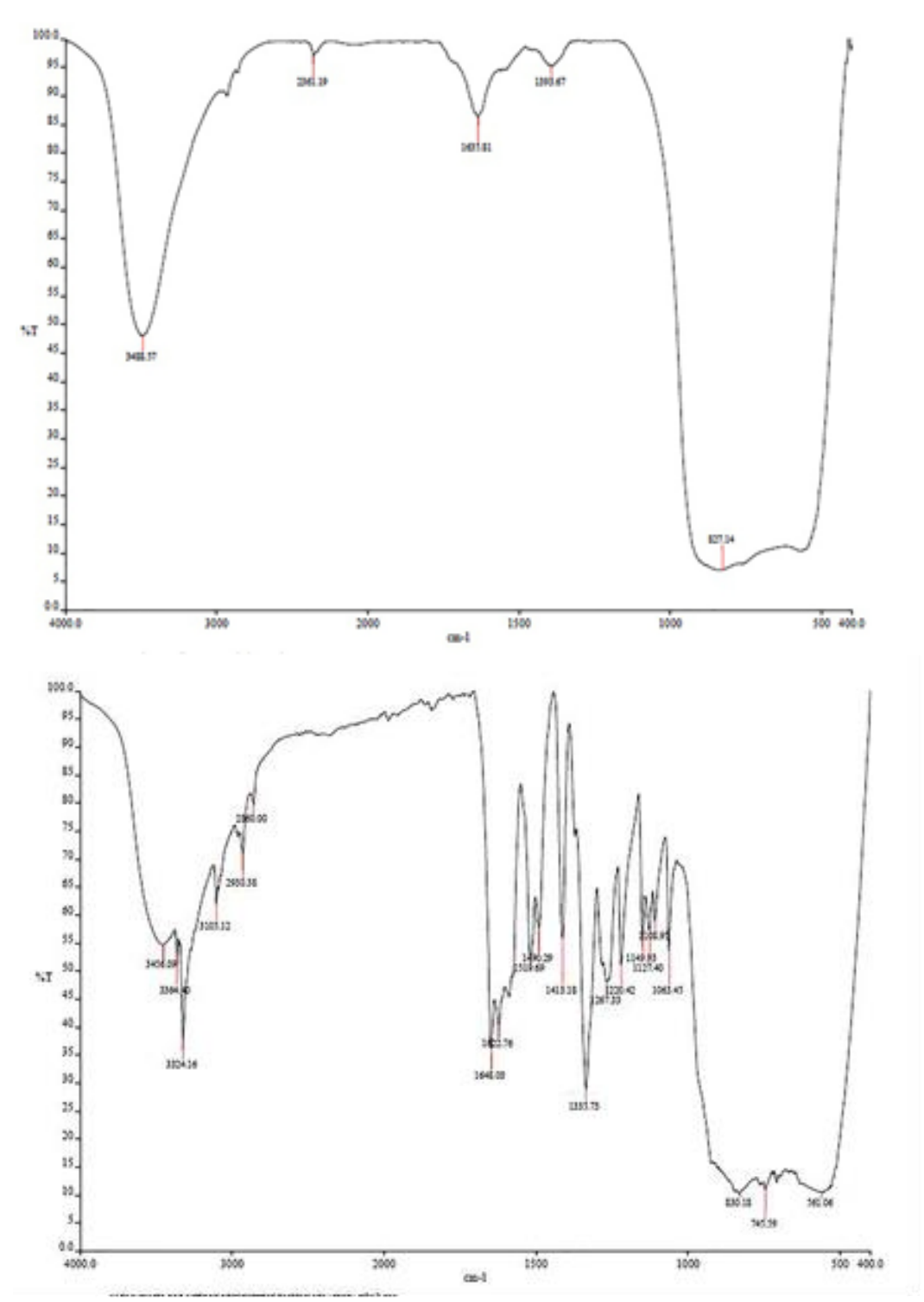

Figure 2. FT-IR spectra of (a) naked $\gamma$-alumina nanoparticles and (b) DNPH- $\gamma$-aluminananoparticles 


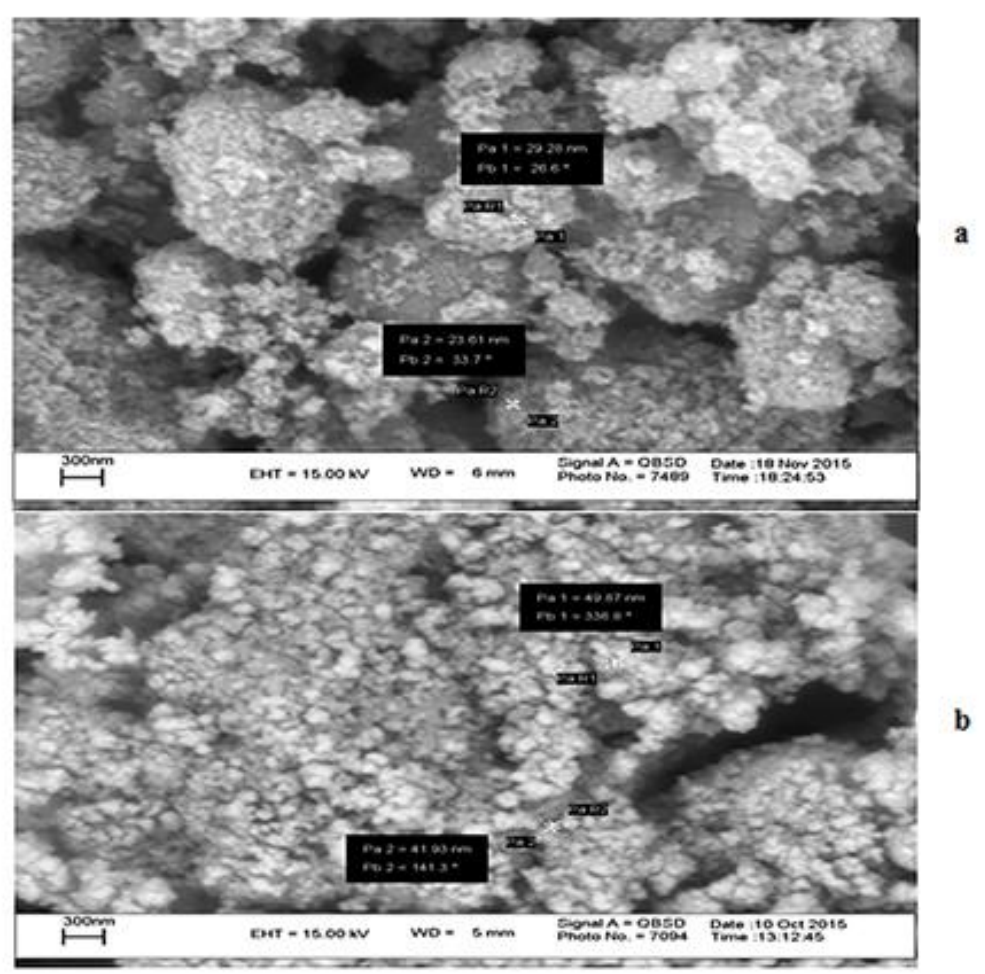

Figure 3. SEM images of (a)naked $\gamma$-alumina nanoparticles and (b) DNPH- $\gamma$-alumina nanoparticles

The surface and textural morphology of the prepared $\gamma$-alumina and DNPH modified $\gamma$-alumina nanoparticles were investigated by scanning microscopy (SEM). The SEM images of $\gamma$-alumina nanoparticles and DNPH modified $\quad \gamma$-alumina nanoparticles are shown in Figure 3. The results from Figure 3a suggested that the naked $\gamma$-alumina nanoparticles have a mean diameter of $53 \mathrm{~nm}$. After modification process, the prepared DNPH m5odified $\gamma$-alumina nanoparticles had a mean diameter of $75 \mathrm{~nm}$ (Figure 3b). These results show that the $\gamma$-alumina nanoparticles have been completely coated by the 2,4dinitrophenyl hydrazine (DNPH). It reveals that the coating process significantly results in the agglomeration and the change in size of the particles.

\section{Results and discussion}

Effect of adsorbent dosage

The amount of adsorbent is an important process parameter to determine the capacity of an adsorbent for a given amount of the adsorbent at the operating conditions. Compared to conventional sorbents, nanoparticle sorbents have higher surface area and shorter diffusion route. These can result in high adsorption capacity, rapid adsorption dynamics and high adsorption efficiencies. Therefore, satisfactory results can be achieved with fewer amounts of nanoparticle sorbents. In the present study, the effect of adsorbent dosage on the removal of selected azo dye was investigated by adding various amounts of adsorbent in the range $10-70 \mathrm{mg}$ into the flask containing $50 \mathrm{~mL}$ of dye solution $(10$ $\mathrm{mg} \mathrm{L}^{-1}$ ) at room temperature. Figure 4 shows the effect of adsorbent dosage on the percentage removal of Everzol Red 3BS dye with nano- $\gamma$-alumina and DNPH modified $\gamma$-alumina nanoparticles (DNPH- $\gamma$-alumina). The results showed that by increasing the amount of nano- $\gamma$-alumina and DNPH modified $\gamma$-alumina nanoparticles 
(DNPH- $\gamma$-alumina) from 10 to $70 \mathrm{mg}$, the percent removal of dye increased from $21.7 \%$ to $34.26 \%$ and from $91 \%$ to $92 \%$, respectively.It can be seen from Figure 4 that the amount of adsorption for Everzol Red 3BS dye was increased with the increase in adsorbent dose. This increase in dye adsorption with adsorbent dosage can be attributed to increased adsorbent surface area and availability of more adsorption sites. The results indicate that DNPH modified $\gamma$-alumina nanoparticles (DNPH- $\gamma$-alumina) have better dye removal efficiency than unmodified nano- $\gamma$-alumina because of their high surface area and high surface energy that could adsorb dyes on its surface.

Therefore, all the subsequent experiments were performed with 10 and $40 \mathrm{mg}$ of nano-adsorbents.

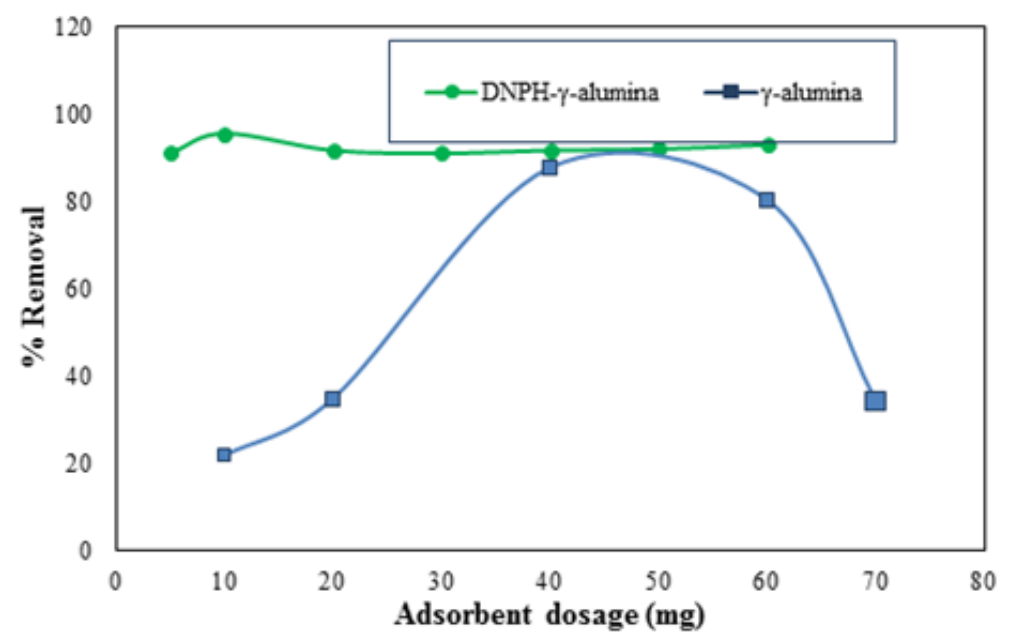

Figure 4. Effect of adsorbent dose on adsorption of Everzol Red 3BS onto nano- $\gamma$-alumina and DNPH-$\gamma$-alumina3.3.2. Effect of initial dye concentration

In this study, the effect of various initial concentrations of Everzol Red 3BS dye (1-60 mg/L) on dye adsorption efficiency and and maximum sorption capacity of nano- $\gamma$-alumina and DNPH modified $\gamma$-alumina nanoparticles (DNPH- $\gamma$-alumina) was evaluated under previously determined optimum conditions. The results are shown in Figure 5. As illustrated in Figure 5, when the dye concentration was increased from 1 to $60 \mathrm{mg} / \mathrm{L}$, the removal percentages of Everzol Red 3BS dye sorbed decreased from 86.34 to 11 in nano- $\gamma$-alumina and from 96.52 to $62.83 \%$ in DNPH modified $\gamma$-alumina nanoparticles (DNPH- $\gamma$-alumina). The decrease in the percentage removal with an increase in dye concentration may be due to the unavailability of sufficient number of active sites required for the adsorption process. Therefore, the optimum initial concentration of dye was selected as $30 \mathrm{mg} / \mathrm{L}$. 


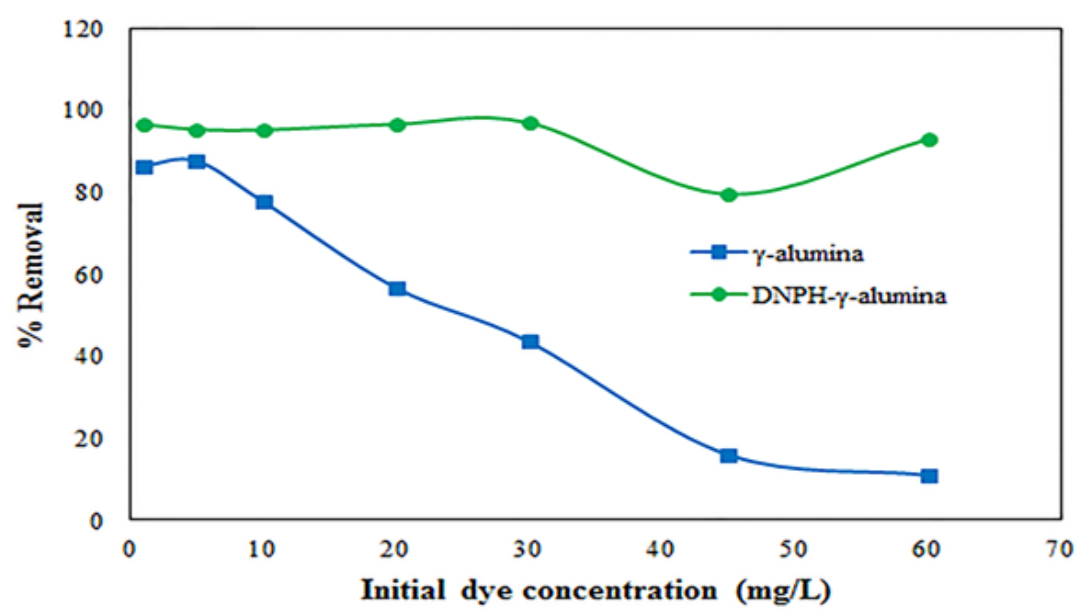

Figure 5. Effect of initial concentration on adsorption of Everzol Red 3BS dye onto nano- $\gamma$-alumina and DNPH- $\gamma$-alumina

\section{Effect of contact time}

The contact time between adsorbate and adsorbent is one of the most fundamental parameters in adsorption. In this work, the effect of contact time on the performance of nano- $\gamma$-alumina and DNPH modified $\gamma$-alumina nanoparticles (DNPH- $\gamma$-alumina) in adsorbing the Everzol Red 3BS dye was investigated in a range from 10 to 150 min. The effect of contact time on the dye removal efficiency of nanoadsorbents are shown in Figure 6. It is seen from Figure 6 that the adsorption of dye increased with the increase in the contact time and reached a constant value. After $60 \mathrm{~min}$ of contact, nano- $\gamma$ alumina and DNPH modified $\gamma$-alumina nanoparticles (DNPH- $\gamma$-alumina) removed the dyes from the solutions, quantitatively. The removal of the dyes was very fast. Such the fast adsorption rates could be referred to the absence of internal diffusion resistance. Therefore, the optimum contact time of 60 min was selected for further works.

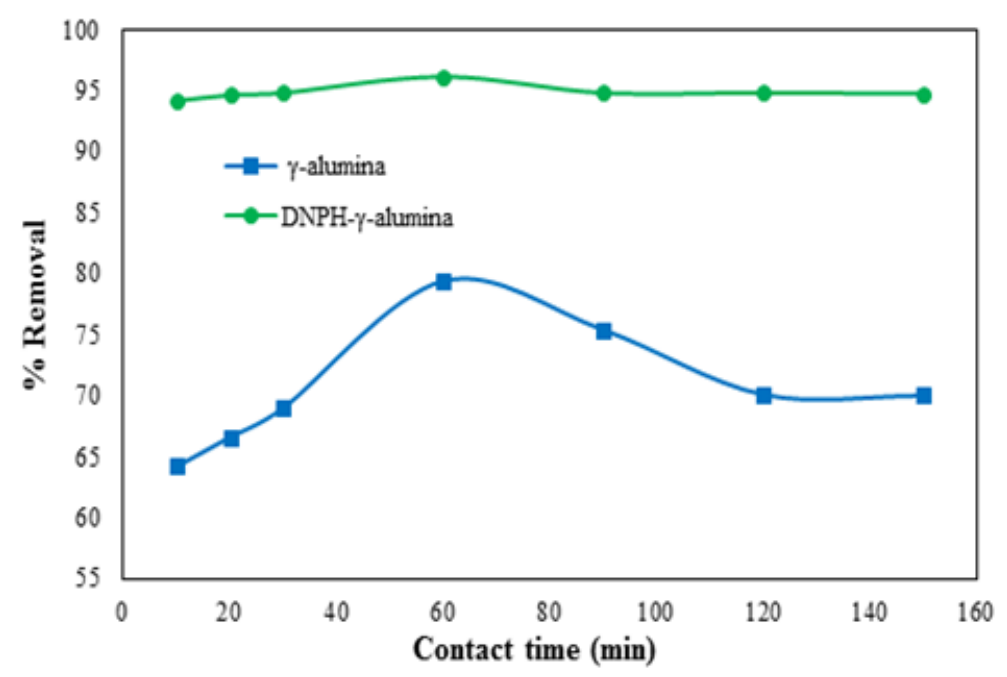

Figure 6. Effect of contact time on the adsorption of Everzol Red 3BS onto nano- $\gamma$-alumina and DNPH$\gamma$-alumina

Effect of solutionpH

The $\mathrm{pH}$ of a dye solution is an important parameter affecting the removal of dyes from aqueous solutions. The solution $\mathrm{pH}$ would affect the surface binding-sites of the 
adsorbent, ionization/dissociation of functional groups on the active sites of the adsorbent and the structure of the adsorbate molecules. In the present study, in order to determine the effect of the initial solution $\mathrm{pH}$ on the adsorption of Everzol Red 3BS dye on nano- $\gamma$-alumina and DNPH modified $\gamma$ alumina nanoparticles (DNPH- $\gamma$ alumina) was studied in the range of 15 at room temperature, while initial dye concentration $(30 \mathrm{mg} / \mathrm{L})$ and adsorbent dose ( 10 and $40 \mathrm{mg}$ ) were kept constant. Figure 5 indicates the results of the effect of the solution $\mathrm{pH}$ on the adsorption of Everzol Red 3BS dye onto nano- $\gamma$-alumina and DNPH modified $\gamma$-alumina nanoparticles (DNPH- $\gamma$-alumina). As it can be seen in Figure 7, the dye removal efficiency increases with reduction of $\mathrm{pH}$.The maximum adsorption of the dye was observed at $\mathrm{pH} 1$ for both adsorbents. From the results it has been deduced that the DNPH modified $\gamma$-alumina nanoparticles (DNPH- $\gamma$-alumina) is more efficient than unmodified nano- $\gamma$ - alumina. Azo Everzol Red 3BS dye is an anionic dyes. In an aqueous solution, anionic dyes carry negative charges due to the presence of sulfonate $\left(\mathrm{SO}^{3-}\right)$ groups. At low $\mathrm{pH}$, a significantly high electrostatic attraction exists between the positively charged surface of the adsorbent, due to the ionization of functional groups of adsorbent and negatively charged anionic dye. As the $\mathrm{pH}$ of the system increases, the number of negatively charged sites increases. A negatively charged site on the adsorbent does not favor the adsorption of anionic dyes due to the electrostatic repulsion. Also, lower adsorption of anionic dyes under alkaline conditions is due to the presence of excess hydroxyl ions on the surface of adsorbent competing with the adsorbate for adsorption sites. So, for the adsorption of anionic dyes, positively charged surface site on the adsorbent seems to be favorable. Hence, pH 1 was selected as an optimum $\mathrm{pH}$ value for performing subsequent studies.

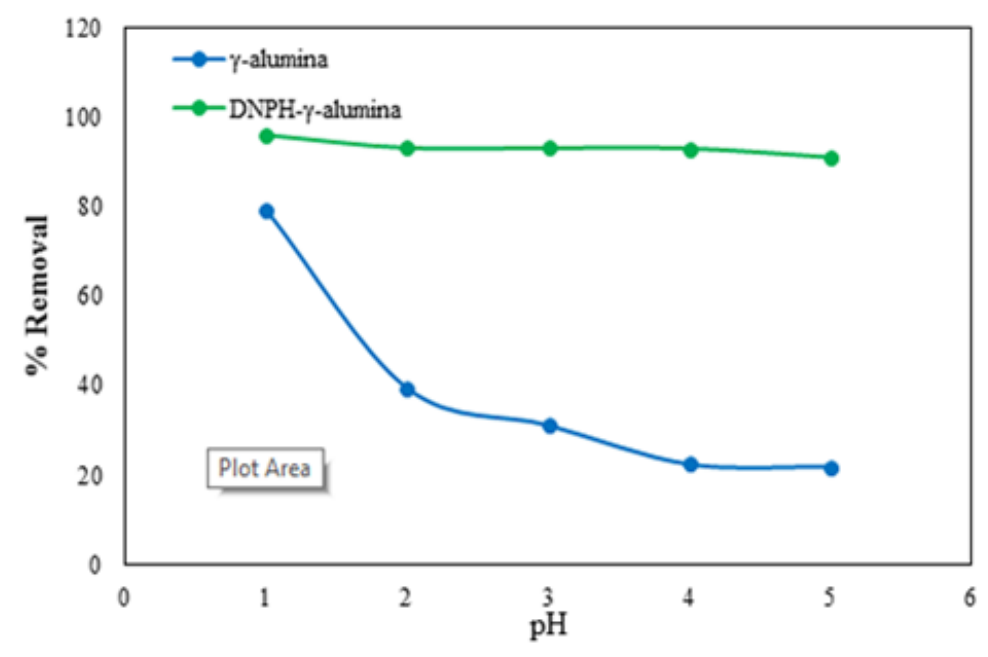

Figure 7. Effect of $\mathrm{pH}$ solution on adsorption of Everzol Red 3BS onto nano- $\gamma$-alumina and DNPH- $\gamma$ alumina

\section{Adsorption isotherms}

The adsorption isotherms described the interaction between adsorbate and adsorbent, and revealed the adsorption capacity of adsorbent.Several isotherm models such as Langmuir, Freundlich and Tempkin, etc. have been used to describe the equilibrium characteristics of the adsorption.In the present study, Langmuir and Freundlich isotherm 
models were applied to describe the adsorption isotherm for Everzol Red 3BS dye onto alumina nanomolecules. The adsorption isotherm of Everzol Red 3BS dye onto nano- $\gamma$ alumina and DNPH modified $\gamma$-alumina nanoparticles (DNPH- $\gamma$-alumina) are shown in Figure 8. The Langmuir isotherm model is based on a monolayer adsorption onto a homogeneous surface of adsorbent with a finite number of adsorption sites of uniform adsorption energies. The linearized form of the Langmuir equation can be expressed as follows:

$$
\frac{\mathrm{C}_{\mathrm{e}}}{\mathrm{q}_{\mathrm{e}}}=\frac{1}{\mathrm{~K}_{\mathrm{L}} \times \mathrm{q}_{\mathrm{m}}}+\frac{\mathrm{C}_{\mathrm{e}}}{\mathrm{q}_{\mathrm{m}}}
$$

Where $\mathrm{q}_{\mathrm{m}}$ is the maximum adsorption capacity $(\mathrm{mg} / \mathrm{g}), \mathrm{q}_{\mathrm{e}}$ is the amount of dye adsorbed on adsorbent at equilibrium $(\mathrm{mg} / \mathrm{g}), \mathrm{C}_{\mathrm{e}}$ is the dye concentration at equilibrium $(\mathrm{mg} / \mathrm{L})$, and $\mathrm{K}_{\mathrm{L}}$ is the Langmuir adsorption constant (L/mg). The Langmuir constants $\left(\mathrm{q}_{\mathrm{m}}\right.$ and $\left.\mathrm{K}_{\mathrm{L}}\right)$ were calculated from the intercept and the slope of the linear plot of experimental data of Ce/qe versus Ce. Figure 9 shows the Langmuir plots for adsorption of Everzol Red 3BS dye onto nano- $\gamma$-alumina and DNPH modified $\gamma$-alumina nanoparticles (DNPH- $\gamma$-alumina).

In contrast, Freundlich isotherm an empirical equation used to describe the adsorption of an adsorbate on a heterogeneous surface of an adsorbent. It can be expressed as the following equation:

$\mathrm{Lnq}_{\mathrm{e}}=\mathrm{LnK}_{\mathrm{F}}+\left(\frac{1}{\mathrm{n}}\right) \mathrm{LnC}_{\mathrm{e}}$

Where $K_{F}$ is the Freundlich constant $(\mathrm{L} / \mathrm{mg})$, and $1 / \mathrm{n}$ is the heterogeneity factor. The $K_{F}$ and $n$ values can be calculated from the intercept and the slope of the linear plot of experimental data of $\ln \mathrm{q}_{\mathrm{e}}$ versus $\mathrm{Ln}$ $\mathrm{C}_{\mathrm{e}}$. (Figure 10). The values of $1 / \mathrm{n}$ shows the type of isotherm to be irreversible $(1 / \mathrm{n}=0)$, favorable $(0<1 / \mathrm{n}<1)$ and unfavorable $(1 / \mathrm{n}>1)$.

The essential features of the Langmuir isotherm can be expressed in terms of a dimensionless separation factor or an equilibrium parameter $\left(\mathrm{R}_{\mathrm{L}}\right)$, which is defined by the following equation:

$$
\mathrm{R}_{\mathrm{L}}=\frac{1}{1+\mathrm{K}_{\mathrm{L}} \cdot \mathrm{C}_{\mathrm{o}}}
$$

where $\mathrm{C}_{\mathrm{o}}$ is the initial dye concentration $(\mathrm{mg} / \mathrm{L})$ and $\mathrm{K}_{\mathrm{L}}$ is the Langmuir adsorption constant $(\mathrm{L} / \mathrm{mg})$. The values of $\mathrm{R}_{\mathrm{L}}$ showsthe nature of adsorption isotherm to be irreversible $\left(\mathrm{R}_{\mathrm{L}}=0\right)$, favorable $\left(0<R_{L}<1\right)$, linear $\left(R_{L}=1\right)$ or unfavorable $\left(\mathrm{R}_{\mathrm{L}}>1\right)$.

The calculated parameters for Langmuir and Freundlich isotherms and the correlation coefficients $\left(\mathrm{R}^{2}\right)$ are given in Table 1. As shown in Table 1, the calculated values of $R_{L}$ were found between 0 and 1 . This implies that the adsorption of the investigated dye on both samples from aqueous solutions is favourable under the conditions used in this study. Evaluating the correlation coefficients $\left(\mathrm{R}^{2}\right)$ from Table 1 revealed that Langmuir model is more suitable for azo dye adsorption ontoboth samples,compared with Freundlich model. This indicates that the adsorption of dyes takes place at specific homogeneous sites and a one layer adsorption onto adsorbent surface. On the basis of the Langmuir analysis, the maximum adsorption capacity $\left(\mathrm{q}_{\mathrm{m}}\right)$ of nano- $\gamma$-alumina and DNPH modified $\gamma$ alumina nanoparticles (DNPH- $\gamma$ alumina) was 10.21 and $86.96 \mathrm{mg} / \mathrm{g}$ for Everzol Red 3BS dye, respectively. It is apparent that modified nano- $\gamma$-alumina is a suitable sorbent for removal of the Everzol Red 3BS dye from aqueous solution with the conditions used in this study. 

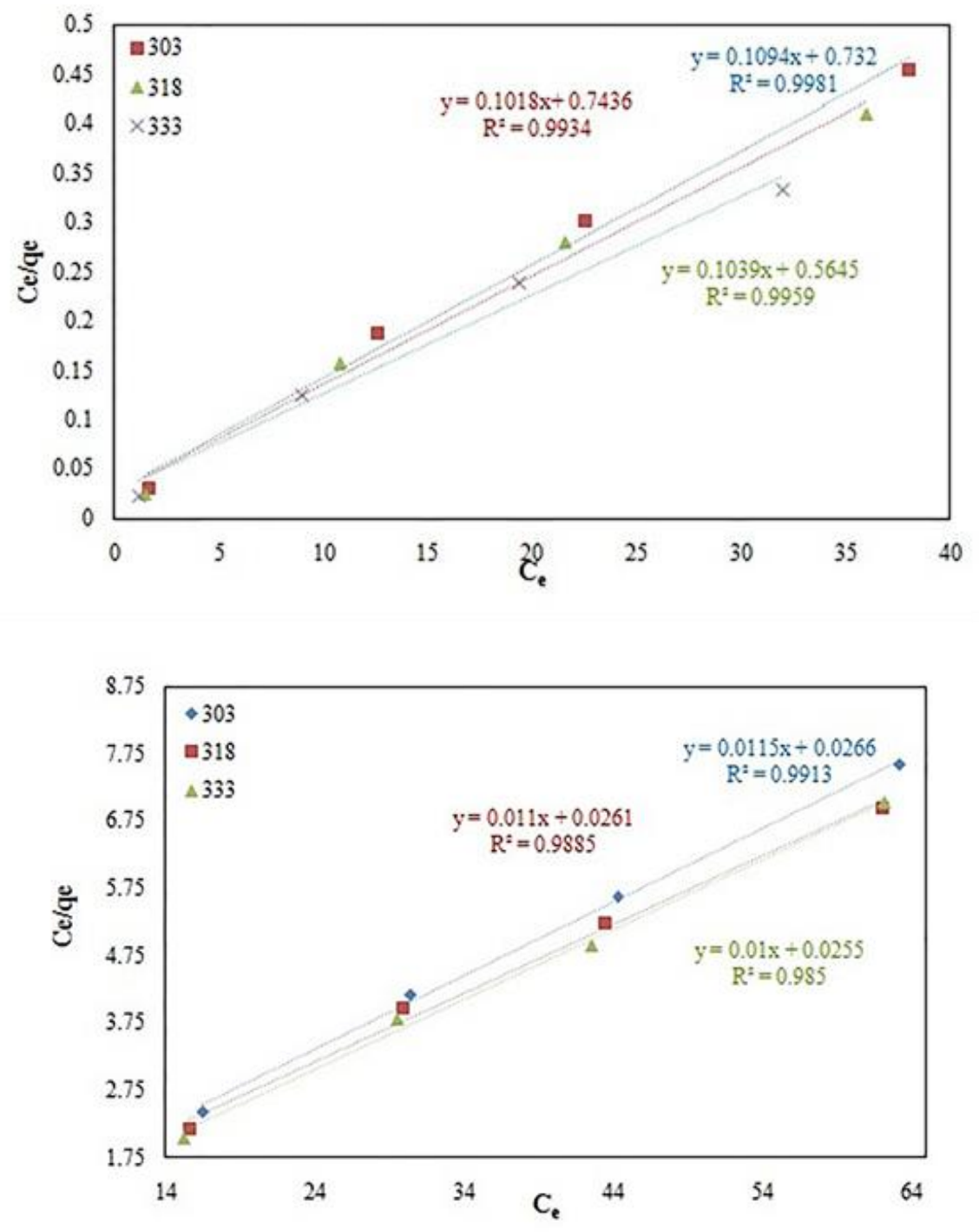

Figure 8. Langmuir isotherm plots for adsorption of Everzol Red 3BS dye on nano- $\gamma$-alumina(a) and DNPH- $\gamma$-alumina(b)

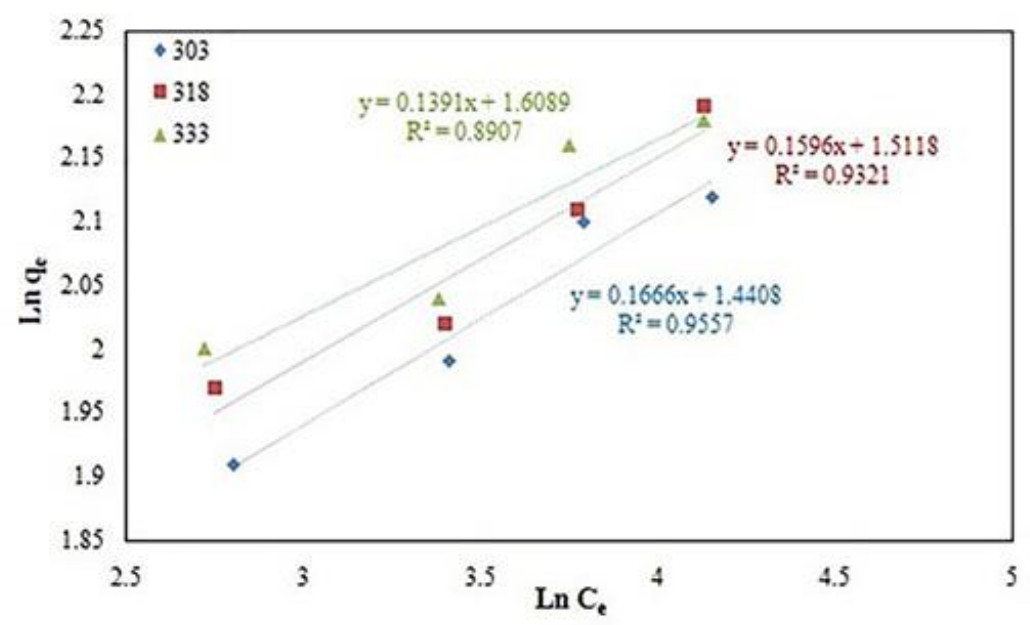




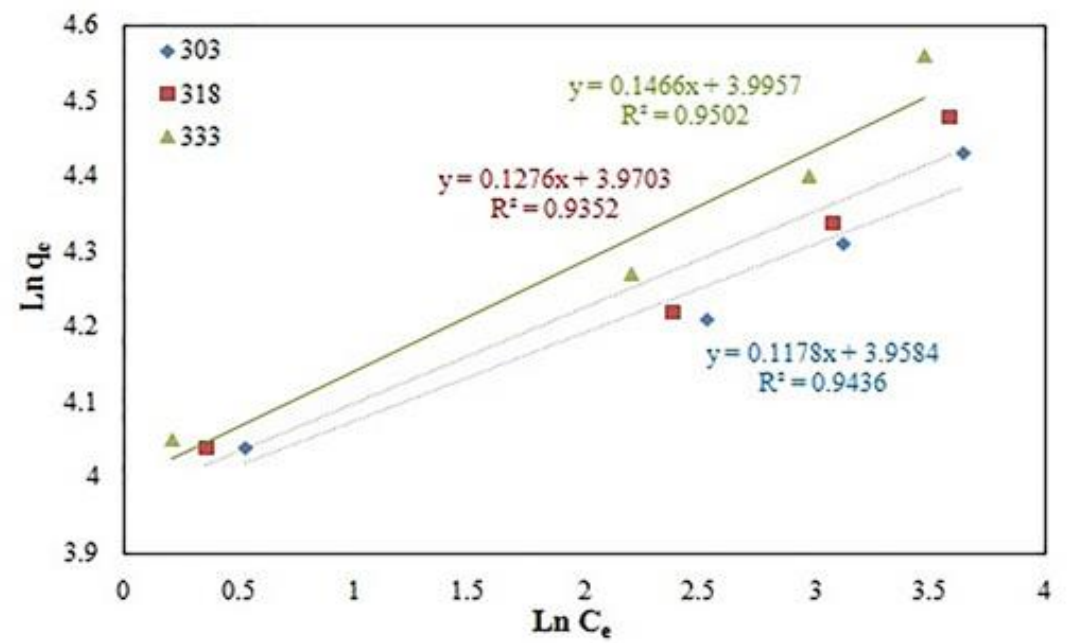

Figure 9. Frendlich isotherm plots for adsorption of Everzol Red 3BS dye on nano- $\gamma$-alumina(a) and DNPH- $\gamma$-alumina(b)

Table 1. Adsorption isotherms parameters for the adsorption of Everzol Red 3BS dye onto nano- $\gamma$ alumina(a) and DNPH- $\gamma$-alumina(b)

Isoterms

Parameters

\section{Temperature $\left({ }^{\circ} \mathrm{C}\right)$}

$\begin{array}{lll}30 & 45 & 60\end{array}$

\begin{tabular}{lllll}
\hline & $\boldsymbol{q}_{\text {max }}(\mathrm{mg} / \mathrm{g})$ & 8.61 & 9.27 & 10.21 \\
& $\boldsymbol{K}_{\boldsymbol{L}}(\mathrm{Lit} / \mathrm{mol})$ & 0.19 & 0.188 & 0.17 \\
Langmuir & $\boldsymbol{R}_{\boldsymbol{L}}$ & 0.06 & 0.062 & 0.068 \\
& $\boldsymbol{R}^{2}$ & 0.9913 & 0.9895 & 0.9828 \\
& & & & \\
Freundlich & $\boldsymbol{K}_{\boldsymbol{F}}(\mathrm{Lit} / \mathrm{mol})$ & 6.48 & 6.62 & 7.07 \\
& $\boldsymbol{R}^{2}$ & 0.34 & 4.7 & 4.99 \\
& & & 0.9423 & 0.9023 \\
\hline
\end{tabular}




\begin{tabular}{|c|c|c|c|c|}
\hline \multirow{2}{*}{ Isoterms } & \multirow{2}{*}{ Parameters } & \multicolumn{3}{|c|}{ Temperature $\left({ }^{\circ} \mathrm{C}\right)$} \\
\hline & & 30 & 45 & 60 \\
\hline \multirow{4}{*}{ Langmuir } & $\boldsymbol{q}_{\max }(\mathrm{mg} / \mathrm{g})$ & 78.12 & 79.36 & 86.96 \\
\hline & $\boldsymbol{K}_{\boldsymbol{L}}(\mathrm{Lit} / \mathrm{mol})$ & 1.43 & 1.61 & 1.64 \\
\hline & $R_{L}$ & 0.008 & 0.0077 & 0.007 \\
\hline & $R^{2}$ & 0.998 & 0.9915 & 0.9936 \\
\hline \multirow{3}{*}{ Freundlich } & $\mathrm{n}$ & 8.39 & 8.69 & 8.83 \\
\hline & $\boldsymbol{K}_{\boldsymbol{F}}(\mathrm{Lit} / \mathrm{mol})$ & 51.95 & 58.91 & 59.1 \\
\hline & $R^{2}$ & 0.9382 & 0.9154 & 0.9578 \\
\hline
\end{tabular}

Table 2. Thermodynamic parameters for the adsorption of Everzol Red 3BS dye at different temperatures onto nano- $\gamma$-alumina(a) and DNPH- $\gamma$-alumina(b)

\begin{tabular}{llll}
\multicolumn{5}{c}{ temperatures onto nano- $\gamma$-alumina(a) and DNPH- $\gamma$-alumina(b) } \\
\hline $\mathbf{T}(\mathbf{K})$ & $\Delta \mathbf{G}^{\mathbf{0}}(\mathbf{k J} / \mathbf{m o l})$ & $\Delta \mathbf{H}^{\mathbf{0}}(\mathbf{k J} / \mathbf{m o l})$ & $\Delta \mathbf{S}^{\mathbf{0}}(\mathbf{k J} / \mathbf{m o l K})$ \\
303 & -4.082 & & \\
318 & -4.46 & 3.55 & 0.025 \\
333 & -4.84 & & \\
\hline \hline
\end{tabular}

\begin{tabular}{llll}
\hline $\mathbf{T}(\mathbf{K})$ & $\Delta \mathbf{G}^{\mathbf{0}}(\mathbf{k J} / \mathbf{m o l})$ & $\Delta \mathbf{H}^{\mathbf{0}}(\mathbf{k J} / \mathbf{m o l})$ & $\Delta \mathbf{S}^{\mathbf{0}}(\mathbf{k J} / \mathbf{m o l K})$ \\
\hline & & & \\
303 & -9.95 & & 0.037 \\
318 & -10.51 & 1.40 & \\
333 & -11.07 & & \\
\hline \hline
\end{tabular}




\section{Thermodynamic studies}

The aim of thermodynamic study is to establish the thermodynamic parameters that can characterize the adsorption process of dye onto adsorbents. In this study, the thermodynamic behaviors of the adsorption of Everzol Red 3BS dye onto nano-adsorbents were investigated at three different temperatures (303, 318 , and $333 \mathrm{~K}$ ) using thermodynamic parameters including the changes in free energy $\left(\Delta \mathrm{G}^{\circ}\right)$, enthalpy $\left(\Delta \mathrm{H}^{\circ}\right)$, and entropy $\left(\Delta \mathrm{S}^{\circ}\right)$. The values of $\Delta \mathrm{H}^{\circ}, \Delta \mathrm{G}^{\circ}$, and $\Delta \mathrm{S}^{\circ}$ were calculated from the following equations:

$\Delta \mathrm{G}^{\circ}=-R T \ln \mathrm{Kc}(6)$

$\Delta \mathrm{G}^{\circ}=\Delta \mathrm{H}^{\circ}-\mathrm{T} \Delta \mathrm{S}^{\circ}(7)$

$$
\operatorname{LnK}_{\mathrm{C}}=\frac{\Delta \mathrm{S}^{\mathrm{o}}}{\mathrm{R}}-\frac{\Delta \mathrm{H}^{\mathrm{o}}}{\mathrm{RT}}
$$

where $\mathrm{R}$ is the universal gas constant $(8.314 \mathrm{~J} / \mathrm{mol} \mathrm{K})$, Tis the reaction temperature $(\mathrm{K})$ and $\mathrm{K}_{\mathrm{c}}\left(\mathrm{q}_{\mathrm{e}} / \mathrm{C}_{\mathrm{e}}\right)$ is the equlibrium constant. The $\Delta \mathrm{H}^{\circ}$ and $\Delta \mathrm{S}^{\circ}$ values were obtained from the slope and intercept of the linear plot of $\ln \mathrm{K}_{\mathrm{c}}$ versus 1/T (shown in Figure 11), respectively. The evaluated thermodynamic parameters are presented in Table 2. The negative values of $\Delta \mathrm{G}^{\circ}$ reported in Table 2 indicate that the Everzol Red 3BS dye adsorption by both nano-adsorbent is spontaneous and favorable processes for all studied temperatures. Also, the positive value of $\Delta \mathrm{H}^{\circ}$ suggests the endothermic nature of adsorption. The positive values of $\Delta \mathrm{S}^{\circ}$ confirms the increased randomness at the solidsolution interface during adsorption process and reveals good affinity towards the dye molecule. The data given in Table 2 show that $\left|\mathrm{H}^{\circ}\right|>\left|\mathrm{TS}^{\circ}\right|$ for both nano-adsorbents at all temperatures. This indicates that the adsorption process is dominated by enthalpic rather than entropic changes.

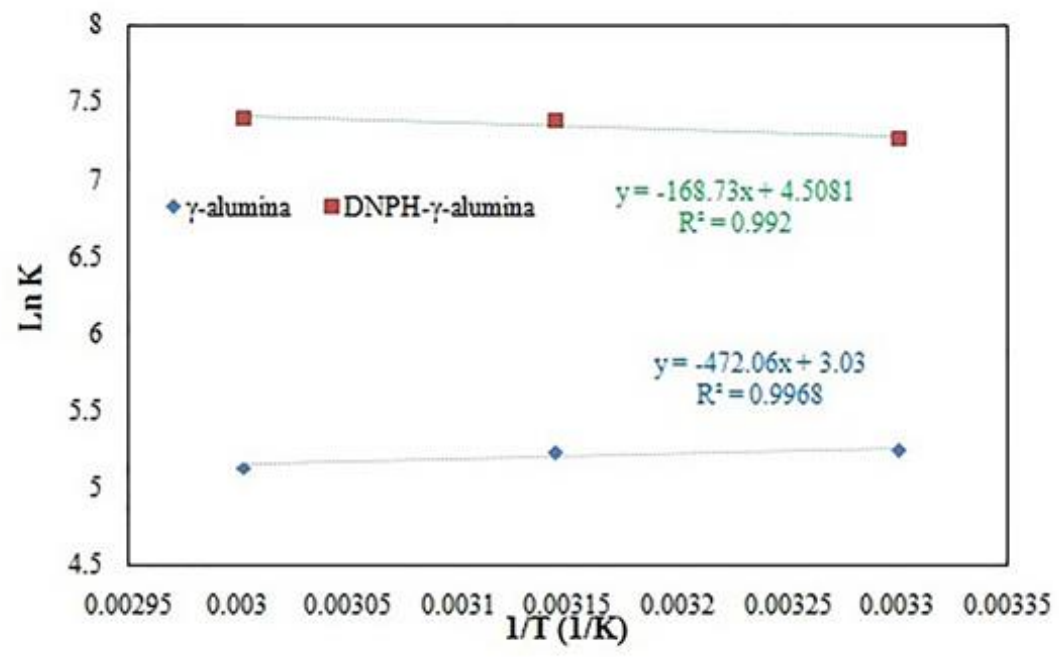

Figure 10. Influence of temperature on the thermodynamic behavior of Everzol Red 3BS dye

\section{Conclusion}

In this paper, 2, 4dinitrophenylhydrazine (DNPH) immobilized on sodium dodecyl sulfate coated nano- $\gamma$-alumina (DNPH- $\gamma$ alumina) was synthesized by a simple and rapid modification method. The nano- $\gamma$-alumina and DNPH- $\gamma$-alumina were successfully used as new and efficient adsorbents for the removal of Everzol Red 3BS dye from aqueous solutions by batch adsorption procedure. These adsorbents were characterized by FT-IR and SEM. The effects of various 
parameters such as contact time, initial dye concentration, adsorbent dose and solution $\mathrm{pH}$ on the adsorption process were investigated. Then, the adsorption isotherm models of adsorption process were determined using Langmuir and Freundlich adsorption isotherms. The optimum dosage, initial concentration of dye, $\mathrm{pH}$ and contact time values for the Everzol Red 3BS adsorption onto nano$\gamma$-alumina and DNPH DNPH- $\gamma$-alumina were obtained to be 10 and $40 \mathrm{mg}, 30$ $\mathrm{mg} / \mathrm{L}, \mathrm{pH} 1$ and $60 \mathrm{~min}$, respectively. The isotherm modeling results indicated that the Langmuir isotherm equation could better describe the adsorption of the Everzol Red 3BS dye onto the both adsorbents as compared to Freundlich model. On the basis of the Langmuir analysis, the maximum adsorption capacity values $\left(\mathrm{q}_{\mathrm{m}}\right)$ of Everzol Red 3BS dye with nano- $\gamma$-alumina and DNPH DNPH- $\gamma$-alumina were 10.21 and $86.96 \mathrm{mg} / \mathrm{g}$ for Everzol Red 3BS dye, respectively. Thermodynamic parameters were calculated and the results indicated that the adsorption process was spontaneous and endothermic in nature. The results achieved from the present study clearly show that the modified $\gamma-\mathrm{Al}_{2} \mathrm{O}_{3}$ nanoparticles are very efficient sorbents for the removal of the selected dye as compared to the naked $\gamma-\mathrm{Al}_{2} \mathrm{O}_{3}$ nanoparticles because of their high specific surface area and nanoscale particle size. Also, it was found that modification of alumina nanoparticles prevents agglomeration of these particles. Finally, it can be concluded that the modified $\gamma$-A12O3 nanoparticles can be used as an alternative sorbent for the removal of some anionic dye molecules from wastewaters.

\section{Acknowledgments}

The authors acknowledge the Payame Noor University, Ardabil, Iran for providzaing facilities for this work.

\section{References}

[1] A. Debrassi, A.F. Correa, Th. Baccarin, N. Nedelko, A. S'lawskaWaniewska, K. Sobczak, P, Dłuz ewski, J.M. Greneche, C.A. Rodrigues, Chem. Eng. J., 2012, 183, 284-293.

[2] H. Chen, Zh. Xu, Y. Huang, Zh. Lin, Y. Zhang, Q. Wang. ICIMM, 2015, 517521.

[3] Y. Liu, J. Li, Y. Yang, B. Li, Appl. Surf. Sci., 2015, 351, 831-839.

[4] G.Z. Kyzas, J. Fu, K.A. Matis, Materials, 2013, 6, 5131-5158.

[5] Y. Du, M. Pei, Y. He, F. Yu, W. Guo, L. Wang, PLOS ONE., 2014, 9, 108647.

[6] S. Ghorai, A.K. Sarkar, A.B. Panda, S. Pal, Bioresource Technol., 2013, 144, 485-491.

[7] E. Forgacsa, T. Cserha'tia, G. Oros, Environ Int., 2004, 30, 953-971.

[8] L. Jin, Q. Sun, Q. Xu, Y. Xu, Bioresour Technol., 2015, 197, 348355.

[9] M. Rafatullah, O. Sulaiman, R. Hashim, A. Ahmad, J. Hazard. Mater., 2010, 177, 70-80.

[10] (a) L. Sheikhian, Desalin Water Treat., 2015, 1-7; (b) S. Sajjadifar, H. Vahedi, A. Massoudi, O. Louie, Molecules, 2010, 15, 2491-2498; (c) S. Sajjadifar, Z. Arzehgar, A. Ghayuri, Journal of the Chinese Chemical Society, 2018, 65, 205-211; (d) S. Sajjadifar, O. Louie, Journal of chemistry, 2013, 2013, http://dx.doi.org/10.1155/2013/674946;

(e) S. Sajjadifar, G. Mansouri, S. Miraninezhad, Asian J. Nanosci. Mater., 2018, 1, 11-18.

[11] J. Axelsson, U. Nilsson, E. Terrazas, T.-A. Aliaga, U. Welander, Enzyme Microb Technol, 2006, 39, 3237.

[12] E.R. Garcí, R.L. Medina, M.M. Lozano, I.H. Pérez, M.J. Valero, A.M.M. Franco, Materials, 2014, 7, 8037-8057. 
[13] M.A. Kamboh, I.B. Solangi, S.T.H. Sherazi, Sh. Memon, J. Hazard. Mater, 2011, 186, 651-658.

[14] Y.F. Lin, H.W. Chen, P.S. Chien, Ch.S. Chiou, Ch.Ch. Liu, J. Hazard. Mater, 2011, 185, 1124-1130.

[15] M. Malakootian, H. Jafari Mansoorian, A. Hosseini, N. Khanjani, Process Safety and Environmental Protection, 2015, 96, 125-137.

[16] A.R. Cestari, E.F.S. Vieira, G.S. Vieira, L.E. Almeida, J. Hazard Mater, 2006, B138, 133-141.

[17] J. Liu, Sh. Ma, L. Zang, Appl. Surf. Sci., 2013, 265, 393-398.

[18] S. Koner, A. Pal, A. Adak, Int. J. Environ. Res., 2012, 6, 995-1006.

[19] Z. Derakhshan, M.A. Baghapour , M. Ranjbar, M. Faramarzian, Health Scope., 2013, 2,136-144.

[20] M.M. Rahman, F.A. Choudhury, M.D. Hossain, M.N.I. Chowdhury, S. Mohsin, M.M. Hasan, M.F. Uddin, N.Ch. Sarker, J Chem Eng., 2012, 27, 65-71.

[21] M. Anbia, M. Lashgari, Chem. Eng. J., 2009, 150, 555-560.

[22] H. Gao, S. Zhao, X. Cheng, X. Wang, L. Zheng, Chem. Eng. J., 2013, 223, 84-90.

[23] A. Afkhami, M. Saber-Tehrani, H. Bagheri, Desalination., 2010, 263, 240248.

[24] N.M. Mahmoodi, Sh. Khorramfar, F. Najafi, Desalination., 2011, 279, 6168.

[25] E. Kalkan, H. Nadarog ${ }^{\natural u}$, N. Celebi, G. Tozsin, Desalin Water Treat., 2014, 52, 6122-6134.

[26] Zh. Xu, W. Li, Zh. Xiong, J. Fang, Y. Li, Q. Wang, Q. Zeng, Desalin Water Treat., 2015, 1-12.

[27] R.D. Ch. Soltani, A.R. Khataee, M. Safari, S.W. Joo, Int Biodeter Biodegr., 2013, 85, 383-391.

[28] H. Gao, T. Kan, S. Zhao, Y. Qian, $\mathrm{X}$. Cheng, W. Wu, X. Wang, L. Zheng, J Hazard Mater, 2013, 261, 83-90.
[29] (a) R.D.Ch. Soltani, A.R. Khataee, M. Safari, S.W. Joo, Int Biodeter Biodegr., 2013, 85, 383-391; (b) S. Sajjadifar, Chemical Methodologies, 2017, 1, 1-11; (c) S. Rezayati, S. Sajjadifar, Journal of Sciences, Islamic Republic of Iran, 2014, 25, 329-337; (d) H. Veisi, D. Kordestani, S. Sajjadifar, M. Hamelian, Iran. Chem. Commun., 2014, 2, 27-33.

[30] I. Safarik, L. Ptackova, M. Safarikova, Eur Cell Mater, 2002, 3, 5255.

[31] F. Chen, Zh. Liu, Y. Liu, P. Fang, Y. Dai, Chem. Eng. J., 2013, 221, 283291.

[32] A.R. Cestari, E.F.S. Vieira, G.S. Vieira, L.P.D. Costa, A.M.G. Tavares, W. Loh, C. Airoldi, J. Hazard. Mater, 2009, 161, 307-316.

[33] L. Zhou, J. Jin, Zh. Liu, X. Liang, Ch. Shang, J Hazard Mater, 2011, 185, 1045-1052.

[34] D. Sun, X. Zhang, Y. Wu, X. Liu, J. Hazard. Mater, 2010, 181, 335-342.

[35] (a) J. Zolgharnein, M. Bagtash, T. Shariatmanesh, Spectrochimica Acta Part A: Molecular and Biomolecular Spectroscopy, 2015, 137, 1016-1028; (b) H. Veisi, A. Sedrpoushan, P. Mohammadi, A.R. Faraji, S. Sajjadifar, RSC Advances, 2014, 4, 25898-25903; (c) S. Sajjadifar, M.A. Zolfigol, G. Chehardoli, S. Miri, International Journal of Chem Tech Research, 2013, 5, 422-429; (d) ER Nezhad, S. Sajjadifar, Z. Abbasi, S. Rezayati, Journal of Sciences, Islamic Republic of Iran, 2014, 25, 127-134.

[36] J. Zolgharnein, M. Bagtash, N. Asanjarani, Journal of Environmental Chemical Engineering, 2014.

[37] (a) Sh. Mahdavi, M. Jalali, A. Afkhami, Clean Techn Environ Policy, 2014; (b) S. Sajjadifar, S. Rezayati, International Journal of ChemTech Research, 2013, 5, 1964-1968 
[38] V.G. Prasanth, K.I. 2013, 2013, Sathiyanarayanan, M. Pathak, http://dx.doi.org/10.1155/2013/203036; International Journal of Frontiers in (c) S. Sajjadifar, International Journal Science and Technology, 2015, 3, 73- of Chem Tech Research, 2013, 5, 38580 . 389; (d) M.A. Zolfigol, H. Vahedi, A. [39] (a) E. Mohammadifar, F. Massoudi, S. Sajjadifar, O. Louie, Shemirani, B. Majidi, M. Ezoddin, Clinical Biochemistry, 2011, 13, S219. Desalination and Water Treatment, [40] A. Afkhami, M. Saber-Tehrani, H. 2014, 1-11; (b) E. Rezaee Nezhad, F. Bagheri, T. Madrakian, Microchim Heidarizadeh, S. Sajjadifar, Z. Abbasi, $\quad$ Acta., 2011, 172, 125-136.

Journal of Petroleum Engineering,

How to cite this manuscript: Ayub Parchebaf Jadid, Gasem Nojameh, Modified nano- $\gamma$-alumina with 2, 4-dinitrophenyl hydrazine as an efficient adsorbent for the removal of everzol red 3BS dye from aqueous solutions. Eurasian Chemical Communications, 2020, 2(4), 475-490. 